\title{
Consequences of a superabundance of larval walleye pollock Theragra chalcogramma in the Gulf of Alaska in 1981
}

\author{
J. T. Duffy-Anderson*, K. M. Bailey, L. Ciannelli \\ Alaska Fisheries Science Center, National Marine Fisheries Service, 7600 Sand Point Way NE, Seattle, Washington 98115, USA
}

\begin{abstract}
Abundances of larval walleye pollock in Shelikof Strait, Gulf of Alaska, in 1981 were far greater than any recorded estimates before that time or since (some patch estimates exceeded 100000 larvae per $10 \mathrm{~m}^{2}$ ). In spite of this extraordinary input, the ensuing 1981 year class was relatively poor. An examination of the feeding habits of larvae collected from inside and outside dense larval patches revealed that in 1981, larval walleye pollock consumed significantly more invertebrate eggs $(\bar{x}=66.7 \%$ of the total diet) and fewer copepod nauplii $(\bar{x}=13.6 \%)$ inside of larval patches relative to outside ( $\bar{x}=11.4$ and $63.2 \%$, respectively). These observations suggest that density dependent competition inside patches may have locally depleted the primary food source, copepod nauplii, prompting a diet switch to a lower quality but more abundant prey resource, invertebrate eggs. Results from a bioenergetics simulation support this theory, indicating that dense patches of walleye pollock larvae in 1981 were capable of exhausting naupliiar prey resources in Shelikof Strait in a relatively short period of time (14 to $40 \mathrm{~d}$ ). Our observations contrast with other studies that suggest that ichthyoplankton exert little or no influence on microzooplankton standing stocks. Rather, we present evidence that, in certain unusual circumstances, particularly dense aggregations of larvae are capable of locally depleting the prey community. Such events may weaken larval condition and exacerbate natural death rates, which may have contributed to the poor recruitment success of the 1981 year class.
\end{abstract}

KEY WORDS: Walleye pollock $\cdot$ Larvae $\cdot$ Food habits $\cdot$ Mortality $\cdot$ Gulf of Alaska

Resale or republication not permitted without written consent of the publisher

\section{INTRODUCTION}

Much research has focused on the potential for food limitation to influence survival of fish early life history stages, although the issue of whether population size is significantly impacted remains unresolved. Some experiments suggest that larval growth may be influenced by variations in prey availability (Pedersen 1993, Van der Meeren \& Næss 1993, Duffy et al. 1996), while others argue that prey concentration has little effect on larval growth and mortality. Cushing (1983) indicated that early larval stages do not exert significant mortality on their food organisms, suggesting that density dependent food-mediated mortality of larval fish in the wild is improbable. Neilsen \& Munk (1998)

\footnotetext{
*Email: janet.duffy-anderson@noaa.gov
}

determined that predation pressure exerted by fish larvae was lower than daily copepod production in the central North Sea, and Pepin \& Penney (2000) argued that even an entire ichthyoplankton community could not substantially impact zooplankton standing stocks in Conception Bay, Canada.

Certain fishes may be more sensitive to the effects of variations in prey availability than others, and evidence suggests that walleye pollock Theragra chalcogramma may be one such species. For example, Clarke (1984) demonstrated that growth of larval walleye pollock in the Bering Sea was influenced by food availability, and Canino et al. (1991) established that gut contents and RNA/DNA ratios of larval walleye pollock were affected by variations in naupliiar abundance in Shelikof Strait, Alaska. Bailey et al. (1995) have shown that, during years of strong winds and low naupliiar abundance, 
walleye pollock larvae from the Gulf of Alaska (GOA) had less food in their guts, lower growth rates, were in worse nutritional condition and experienced higher rates of mortality than during a year of calm winds. Finally, Theilacker et al. (1996) provided evidence that a significant number of walleye pollock larvae were starving in Shelikof Strait in a year of low prey levels. Based on these observations, it is plausible that larval walleye pollock may be vulnerable to the effects of suboptimal feeding conditions and susceptible to density dependent regulation of larval abundance.

Shelikof Strait is a large, well-established spawning site for walleye pollock. Typical abundances of larval walleye pollock entrained in patches near Shelikof Strait range from approximately 1000 to 6000 larvae per $10 \mathrm{~m}^{2}$ in April (as determined from ICHBASE, a $20 \mathrm{yr}$ ichthyoplankton database maintained at the Alaska Fisheries Science Center, Seattle, WA). These estimates of average pollock densities are high, even compared to previously reported ichthyoplankton densities that are integrated over an entire ichthyoplankton community $\left(0.01\right.$ to $10 \mathrm{~m}^{-3}$; Pepin \& Penney 2000). However, in 1981, a superabundance of pollock larvae was noted, with some patch estimates exceeding 100000 larvae per $10 \mathrm{~m}^{2}$. Interestingly, the resulting 1981 year class of walleye pollock was relatively poor in spite of this extraordinarily large larval input.

Data directly linking poor feeding history and larval density in the field are generally lacking, not only for walleye pollock larvae, but among marine fishes in general. It seemed that if density dependent mortality were to occur during the larval phase, a most unusual set of circumstances would be required to drive the event. Therefore, we were particularly interested to learn whether the extraordinarily high larval abundances in 1981 could have motivated density dependent competition for food resources. Such a scenario might result in high rates of late larval mortality once prey resources became limiting. Interestingly, an initial examination of rates of larval walleye pollock mortality in 1981 revealed a pattern of decline consistent with this hypothesis. Counter to more traditional models, mortality appeared to be low during the early larval stages and increase with larval age. As such, we felt that a more thorough investigation of the events in 1981 was warranted.

Walleye pollock larvae that had been collected in Shelikof Strait, Gulf of Alaska in 1981 were archived at the University of Washington Larval Fish Collection (UWLFC), Seattle, WA, and were available for reexamination. Unfortunately, appropriately sized microzooplankton samples were not collected in that year, rendering a direct comparison of larval stomach contents and field samples of microzooplankton prey impossible. Instead, we used inferences based on gut contents and a bioenergetic model to test the hypothesis that the unusually high larval densities in 1981 may have precipitated density dependent competition for microzooplankton standing stocks, contributing to the low overall cohort success of the 1981 year class.

\section{MATERIALS AND METHODS}

Field collections. Ichthyoplankton samples were collected from Shelikof Strait and the western GOA during 3 separate National Marine Fisheries Service research cruises in 1981. The first cruise, 3MF81 (April 26 to May 2), was conducted in early spring with the NOAA RV 'Miller Freeman' and 2 others, 4MF81 (May 20 to May 24) and 3SH81 (May 20 to May 28), were conducted in late spring with the RV 'Miller Freeman' and the RV 'Shantar', respectively. Collections were made along survey grids beginning in Shelikof Strait and proceeding southwest of Kodiak Island, AK (Fig. 3 ). The grids of 2 of the 3 cruises were identical (3MF81 and $4 \mathrm{MF} 81$ ) and the grid for the third (3SH81) was extended downstream to compensate for presumed larval drift. Ichthyoplankton samples were collected at each grid station with MARMAP double oblique tows (Posgay \& Marak 1980) using paired $60 \mathrm{~cm}$ bongo nets fitted with $505 \mathrm{~m}$ mesh. Flowmeters were fitted into the mouth of each net and all tows were made from $200 \mathrm{~m}$ (depth permitting) to the surface. Upon retrieval, all samples were immediately preserved in sodium borate buffered $5 \%$ formalin. Samples were collected from 'in-patch' and 'out-of-patch' locations based on density distributions of larvae. A patch (in-patch) was defined as at least 10000 larvae per $10 \mathrm{~m}^{2}$ during the early cruise and at least 1000 larvae per $10 \mathrm{~m}^{2}$ during the late spring cruises, although most in-patch samples were 3 to 4 times these values. Samples from outside of patches (out-of-patch) were generally 4 to 5 times less dense than in-patch samples (Fig. 1). Criteria for inpatch and out-of-patch in 1981 were made relative to densities in-patch versus out-of-patch in other years in Shelikof Strait (Canino et al. 1991, Stabeno et al. 1996).

Laboratory analyses. Ichthyoplankton samples were sorted at the Polish Plankton Sorting Center in Szczecin, Poland. All walleye pollock larvae were identified, removed and transferred to $70 \%$ ethanol. Samples of larvae from all stations on each cruise were stored in the UWLFC until used in the current investigation. All data relevant to sample collection (i.e. geographic coordinates, date/time collected, gear used, fishing depth, tow time, number of larvae collected, etc.) were archived in ICHBASE.

Mortality. Cohort-specific larval mortality rates between the early- and late spring cruises were examined (see 'Introduction'). A complete description of the 


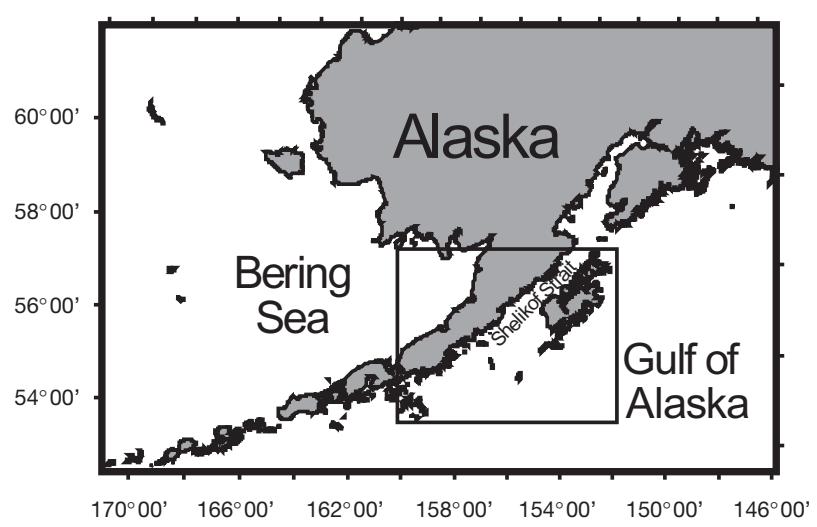

Fig. 1. Theragra chalcogramma. Distribution and abundances of larvae during each of the research cruises conducted in 1981 in Shelikof Strait, AK. (๑) Samples collected from inside patches that were used in gut content analyses. ( $($ ) Samples collected from outside patches that were used in gut content analyses

methods used is provided in Bailey et al. (1996a). Briefly, mortality rates were determined by estimating larval loss between the early (3MF81) and late spring cruises (4MF81 and 3SH81). A subset of 50 larvae (or all the larvae in the sample if fewer than 50 were collected) from each survey station were measured for standard length $(\mathrm{mm})$ and the mean length of the subsample was extrapolated to the entire sample collected at each station. Otolith samples were not collected in 1981; therefore, age was estimated using a Schnute (1981) growth model based on average growth rates from 1985 to $1996\left(G_{\mathrm{L}}=0.196 \mathrm{~mm} \mathrm{~d}^{-1}\right)$. Larval pollock lengths and ages were extrapolated to reflect what they would have been on the mean date of each survey. These corrections provided data that simulated collections all on $1 \mathrm{~d}$ rather than daily collections over the course of a cruise. Mortality estimates were made based on the abundance-at-age estimate from sequential surveys:

$$
z_{\mathrm{a}}=\left[\ln \left(C_{1, \mathrm{a}}\right)-\ln \left(C_{2, \mathrm{a}}\right)\right] / t_{2}-t_{1}
$$

where $z_{\mathrm{a}}=$ mortality for Cohort a, $C_{1, \mathrm{a}}=$ number of larvae of Cohort a in Survey 1, $C_{2, a}=$ number of larvae of Cohort a in Survey 2, and $t_{2}-t_{1}=$ elapsed time between mean survey dates. Mortality estimates were then plotted as mean larval age (weighted for abundance) versus instantaneous mortality rate and compared to previously determined estimates of larval mortality in the GOA in other years. Independently, the mortality rates over the period between the late larval stage in May and the Age- 0 juvenile stage in September were calculated from an age-specific life table analysis as detailed in Bailey et al. (1996b).

Body measurements and gut contents. Appropriate samples from each cruise were identified from $\mathrm{ICH}$ -
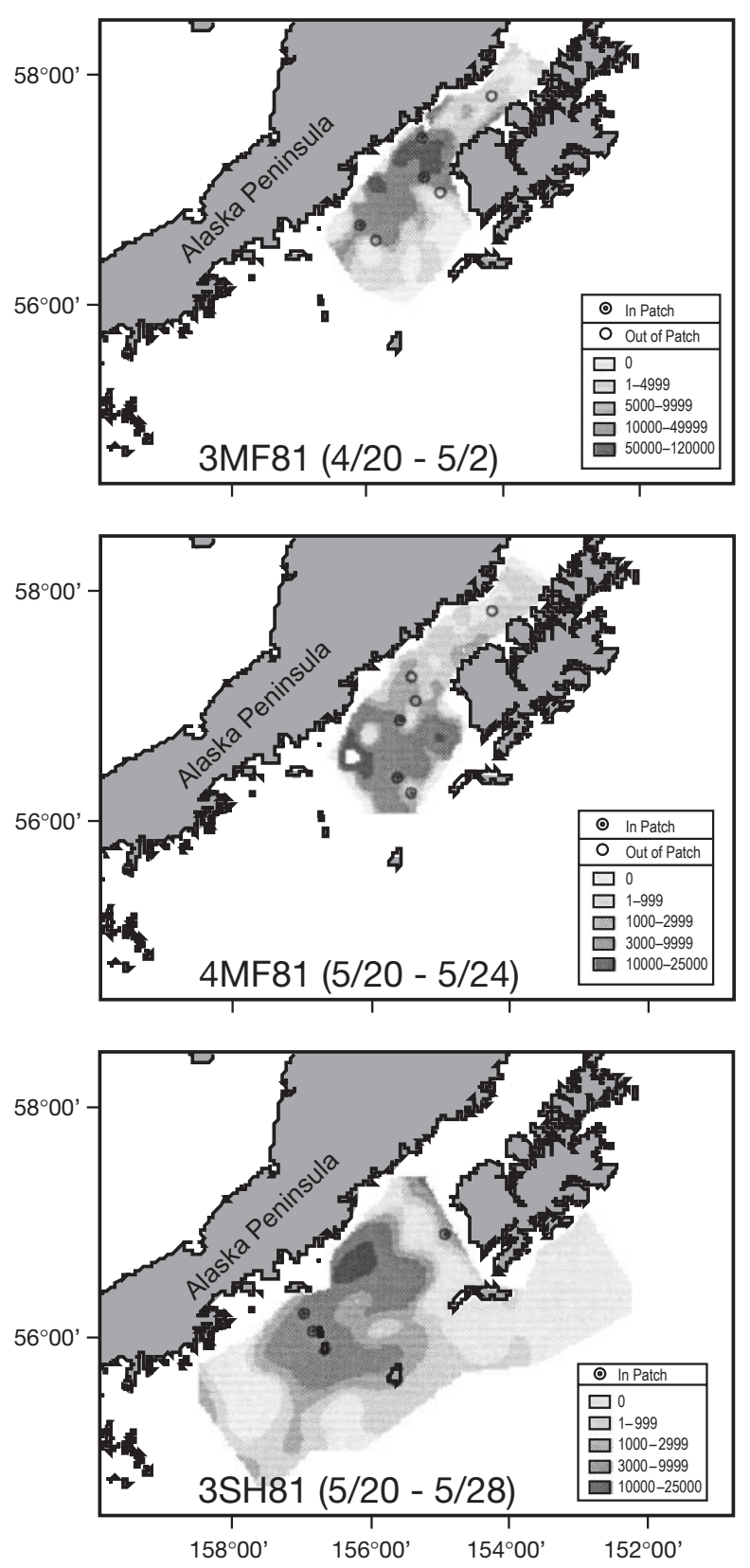

BASE for gut content analyses based on density (number of larvae per $10 \mathrm{~m}^{2}$; inside or outside of a larval patch), time collected and sample availability. Approximately 25 walleye pollock larvae were randomly selected from each station of interest and were measured to the nearest $0.1 \mathrm{~mm}$ standard length (SL) using a dissecting microscope and an ocular micrometer. Measurements of body depth at anus (myotome height) were made to the nearest $0.01 \mathrm{~mm}$ to provide an index of larval condition (Yin \& Blaxter 1986). The entire digestive tract of each larva was excised and the contents were removed and identified. Prey items were measured for length and width (nearest $10 \mu \mathrm{m}$ ). 
Prey organisms from larval guts were identified to the lowest possible taxon and then pooled into broader categories: copepods (including copepodid stages), copepod nauplii, invertebrate eggs and other. The last category comprised a variety of relatively rare organisms including rotifers, euphausiids, crustacean larvae (non-copepod), larvaceans, polychaetes and other material that was too digested to be identified further. Variations in diel feeding were controlled by selecting samples that were collected between 11:00 and 15:00 h (Alaska local time). This time interval provided larvae that potentially contained full guts in stasis with egestion at the time of collection (Canino \& Bailey 1995).

Statistical analyses. Differences in larval size (SL) and anal body depth were examined between cruises and in-patch versus out-of-patch using a crossed, multiway ANOVA model. Significant differences in percentage of larvae feeding between cruises and in-patch versus out-of-patch were determined using a 2-way ANOVA model on arcsin transformed values. In all cases, inference was determined at $\alpha=0.05$.

We used analysis of covariance (ANCOVA) to determine whether the rate of increase (change in time/ length) in anal body depth of larvae collected in 1981, a poor year class, was different from the rate of increase of larvae collected in the GOA in 1988, a strong recruitment year. We chose samples collected from 7 stations in 1988 that were similar in geographic location to those collected in 1981, and samples were selected from inside and outside of a larval patch. Sample availability was more limited in 1988 and we found it necessary to extend the hours of collection to all daylight hours. All selected samples were collected between 07:00 and 20:00 h Alaska local time. Since we were interested in morphometrics only, and not in feeding and diet in this year, this approach was deemed appropriate. It should also be noted that samples from 1988 were collected in $1 \mathrm{~m}$ Tucker trawls, not in $60 \mathrm{~cm}$ bongo nets as in 1981. Shima \& Bailey (1994) have previously shown that bongo tows and $1 \mathrm{~m}$ Tucker trawls catch similar numbers and size distributions of larval walleye pollock, concluding that the 2 gears were interchangeable. Therefore, although the gears used in the 2 yr were dissimilar, the catches were comparable. All other treatment, preservation and storage of samples from 1988 occurred in a similar manner to those of 1981.

The data fit a parametric model, so we initially used a crossed MANOVA design to determine whether there were differences in numbers and types of prey consumed by larvae in-patch versus out-of-patch (Zar 1984). This approach indicated a significant interaction between the 2 factors (cruise, patch, $\mathrm{p}=0.04$ ); therefore, separate MANOVAs were conducted on data from each cruise to determine whether there were significant differences in numbers and types of prey consumed by larvae in-patch versus out-of-patch $(\alpha=0.05)$.

Microzooplankton. As noted previously, microzooplankton samples were not collected from the GOA in 1981; therefore, they were not available for comparison to larval gut content data. We used zooplankton data collected from Shelikof Strait in subsequent years (1985 to 1989 , Incze \& Ainaire 1994) as proxy data in a bioenergetic model to examine the potential impact of larval population consumption on the hypothetical microzooplankton standing stock (Table 1). Some adjustments to the data presented in Incze \& Ainaire (1994) were made. In their paper, microzooplankton densities were integrated over a $60 \mathrm{~m}$ depth, providing a mean zooplankton abundance for the whole water column. These authors also provided data indicating that copepod nauplii tended to be concentrated in the upper water column ( 0 to $30 \mathrm{~m}$ ), where they co-occurred with pollock larvae. Much lower microzooplankton densities occurred below $30 \mathrm{~m}$. Therefore, integrating naupliiar densities over the

Table 1. Spring microzooplankton densities (ind. $\mathrm{m}^{-2}$ ) in Shelikof Strait, Gulf of Alaska. Adapted from Incze \& Ainaire (1994)

\begin{tabular}{|lccccc|}
\hline Prey item & 1985 & 1986 & 1987 & 1988 & 1989 \\
\hline Copepod nauplii & $4.0 \times 10^{5}$ & $8.3 \times 10^{5}$ & $9.7 \times 10^{5}$ & $5.8 \times 10^{5}$ & $5.8 \times 10^{5}$ \\
Other nauplii & $3.2 \times 10^{3}$ & $1.2 \times 10^{4}$ & $1.0 \times 10^{4}$ & $4.0 \times 10^{3}$ & $1.1 \times 10^{4}$ \\
Invertebrate eggs & $2.0 \times 10^{5}$ & $6.3 \times 10^{5}$ & $2.3 \times 10^{5}$ & $2.1 \times 10^{4}$ & $3.1 \times 10^{4}$ \\
Ovisacs & $2.4 \times 10^{4}$ & $1.2 \times 10^{4}$ & $1.0 \times 10^{4}$ & $1.4 \times 10^{4}$ & $1.1 \times 10^{4}$ \\
Copepods & $7.2 \times 10^{4}$ & $3.6 \times 10^{4}$ & $1.0 \times 10^{4}$ & $2.8 \times 10^{4}$ & $2.3 \times 10^{4}$ \\
Euphausiids & $3.2 \times 10^{3}$ & 0 & $1.0 \times 10^{4}$ & 0 & 0 \\
Rotifers & $3.2 \times 10^{3}$ & $1.3 \times 10^{5}$ & $2.5 \times 10^{5}$ & $4.0 \times 10^{3}$ & $3.1 \times 10^{4}$ \\
Tintinnids & $1.6 \times 10^{4}$ & $1.2 \times 10^{4}$ & $2.0 \times 10^{5}$ & $4.0 \times 10^{3}$ & $1.1 \times 10^{4}$ \\
Larvaceans & $3.2 \times 10^{3}$ & $5.4 \times 10^{4}$ & $0 \times 10^{3}$ & $1.1 \times 10^{4}$ \\
Polychaetes & $3.2 \times 10^{3}$ & $1.2 \times 10^{4}$ & $1.0 \times 10^{4}$ & $4.0 \times 10^{3}$ & $1.1 \times 10^{4}$ \\
Echinoderms & $3.2 \times 10^{3}$ & $1.2 \times 10^{4}$ & $1.0 \times 10^{4}$ & $4.0 \times 10^{3}$ & $1.1 \times 10^{4}$ \\
Foraminifera & $3.2 \times 10^{3}$ & $1.2 \times 10^{4}$ & $1.0 \times 10^{4}$ & $4.0 \times 10^{3}$ & $1.1 \times 10^{4}$ \\
Other & $6.4 \times 10^{4}$ & $5.4 \times 10^{4}$ & $7.2 \times 10^{4}$ & $3.5 \times 10^{4}$ & $2.3 \times 10^{4}$ \\
Total & $8.0 \times 10^{5}$ & $1.8 \times 10^{6}$ & $1.8 \times 10^{6}$ & $7.1 \times 10^{5}$ & $7.7 \times 10^{5}$ \\
\hline
\end{tabular}


water column artificially deflated zooplankton densities (to $10^{4}$ nauplii $\mathrm{m}^{-2}$ ). Accordingly, we adjusted their data to surface water concentrations to reflect densities of microzooplankton that might be encountered by pollock larvae in a patch. This procedure provided an estimate of abundance that was in accordance with previously reported estimates of microzooplankton in patches (Canino et al. 1991, Paul et al. 1991, Napp et al. 1996).

Bioenergetics model. The objective of the bioenergetics analysis was to test whether high in-patch densities of walleye pollock larvae in 1981 were capable of depleting local copepod nauplii resources, motivating a diet switch to new prey stages or taxa that were either more abundant or capable of faster turnover rates. The general model used to calculate larval pollock consumption was based on the Winberg (1956) balanced energetics equation (Table 2A).

The model currency was carbon. Larval pollock carbon content was set to $43.4 \%$ of dry weight (Nishiyama 1981), and prey carbon content data were derived from a variety of databases including Incze et al. (1984) for copepod nauplii, Gomez-Gutierrez \& Peterson (1999) for copepod eggs, and Incze et al. (1997) for copepodids and adult copepods. In metabolic calculations, volume units of $\mathrm{O}_{2}$ were converted into mass units of $\mathrm{C}$ and vice versa by applying the following equivalence: $1 \mathrm{ml} \mathrm{O}_{2}=0.428 \mathrm{mgC}$ (Nishiyama 1981). Submodel portions of the Winberg (1956) equation are shown in Table 2A. The full model has already been parameterized for juvenile walleye pollock by Ciannelli et al. (1998). In this study, we kept the same model structure previously developed for juvenile pollock, but adapted the model parameters to the pollock larval stage (Table 2B). Moreover, egestion and excretion were modeled as a single fraction value $(F U)$ of total ingestion. Each prey item was assigned a specific $F U$, to explicitly account for different assimilations among different prey items. Nauplii $F U$ was set to 0.3 (Yamashita \& Bailey 1989), while eggs $F U$ was arbitrarily set to 0.6 to account for the poor assimilation of invertebrate eggs by walleye pollock larvae (Duffy-Anderson pers. obs.).

Model simulation. Two parallel simulations were run for a $45 \mathrm{~d}$ period; one to simulate larval consumption in-patch and the other to simulate larval consumption out-of-patch in 1981. A third simulation, 'normalin-patch', was performed using a maximum in-patch larval density observed during a period of more typical high larval abundance estimates (1982 to 1998) in the GOA (6000 larvae per $10 \mathrm{~m}^{2}$; Fig. 2). The normalin-patch model was run to provide a worst case scenario estimate of in-patch consumption during years of average larval density. All simulations hypothetically began in April, at the time of the peak of abundance of first-feeding walleye pollock in Shelikof Strait. We conservatively set the mean in-patch larval abundance in 1981 to 27440 larvae per $10 \mathrm{~m}^{2}$, the mean density of all stations located within the general geographic extent of the large larval aggregation (Fig. 1).

Environmental data required to run the bioenergetics model were water column temperature, larval growth, larval diet and prey density. Temperatures were derived from CTD casts conducted at the time of sampling. Instantaneous growth rates $\left(G_{\mathrm{W}}, \mathrm{d}^{-1}\right)$ in 1981 were calculated for in-patch and out-of-patch larvae from estimates of larval dry weight between early and late spring cruises (Table 3). In turn, larval dry weights were extrapolated from measurements of larval standard length and published regressions between larval

Table 2. (A) Submodels of larval walleye pollock bioenergetic functions; $W=$ weight $(\mathrm{g})$ and $T=$ temperature $\left({ }^{\circ} \mathrm{C}\right)$. Parameter symbols are explained in (B) and in Hewett \& Johnson (1992). (B) Descriptions and values of the parameters used in a bioenergetics model of larval walleye pollock

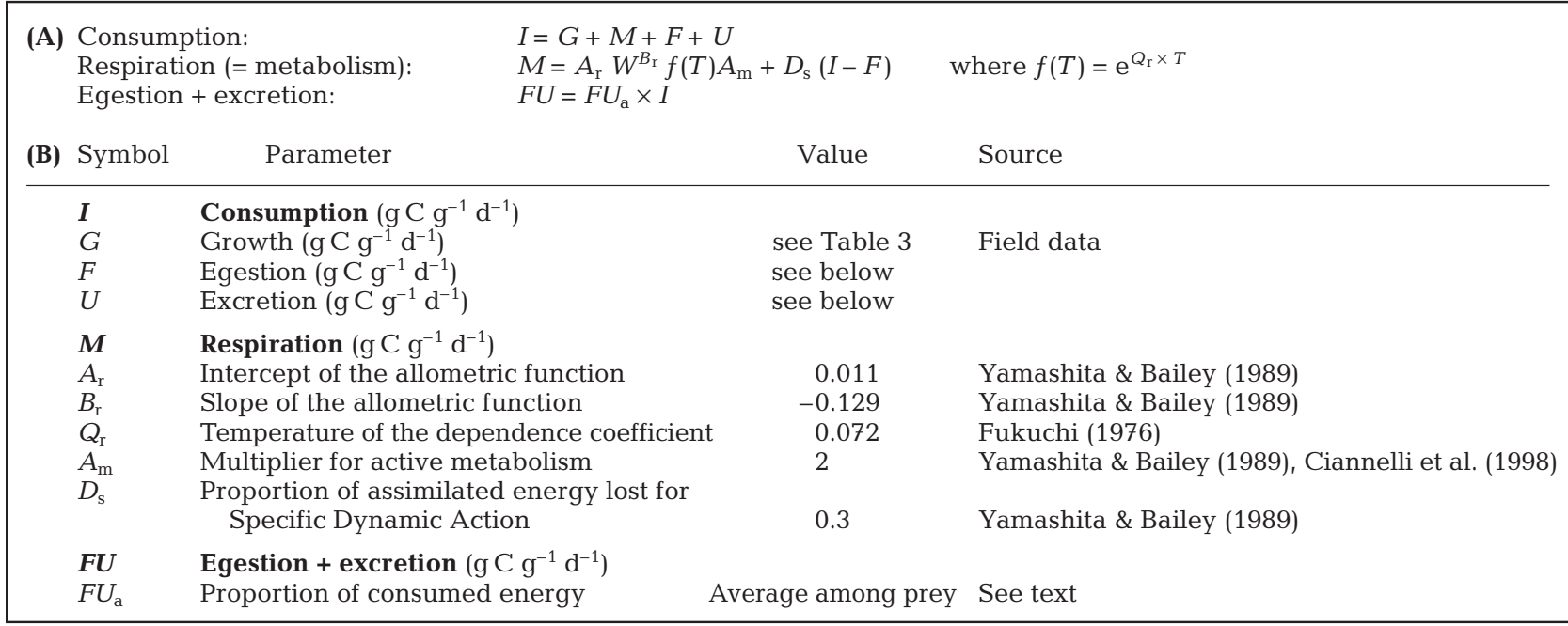




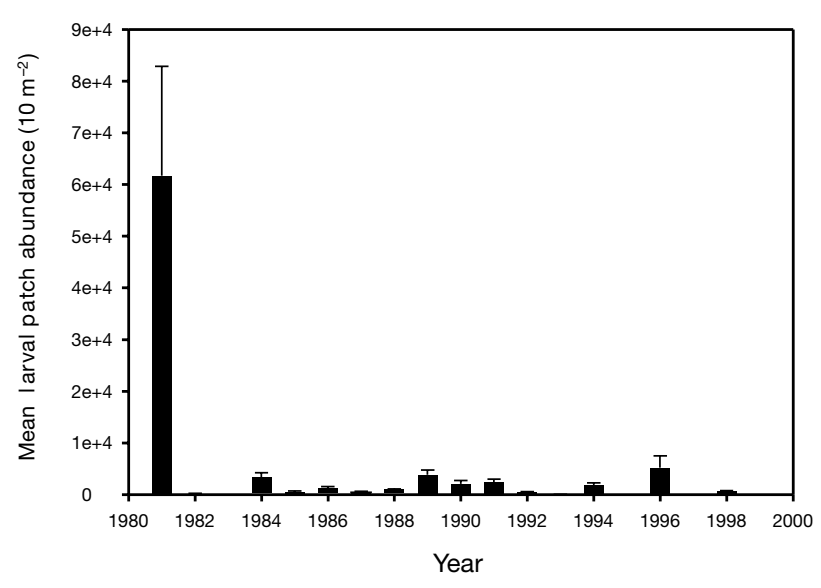

Fig. 2. Theragra chalcogramma. Yearly comparison of observed abundances (mean + SE) of larval walleye pollock in April in the western Gulf of Alaska. Data were derived from ICHBASE, Alaska Fisheries Science Center, Seattle, WA. Data from several years were not available due to lack of sampling at the appropriate time

walleye pollock length and weight (Nishiyama 1981). Calculated $G_{\mathrm{W}}$ estimates were slightly higher among in-patch larvae $\left(0.071 \pm 0.02 \mathrm{SD} \mathrm{d}^{-1}\right)$ than out-of-patch larvae $\left(0.067 \pm 0.01 \mathrm{SD} \mathrm{d}^{-1}\right)$, although it was determined that there were no significant differences in $G_{\mathrm{W}}$ in-patch versus out-of-patch $(p>0.05)$. Larval pollock diets, used in all bioenergetics simulation types, were derived from published data during a year of normal larval abundance (1989) in the GOA (Canino et al. 1991). Since the unusual diet composition of in-patch larvae observed in the 1981 samples (see below for diet results) could have already been the result of a diet switch, we felt that it was more appropriate to run the bioenergetics model with a diet characteristic of a year of more typical larval abundance (patch densities $<5000$ larvae per $10 \mathrm{~m}^{2}$ ) to simulate the presumed initial foraging strategy of larvae feeding in 1981. The results of all simulations were then compared with available estimates of zooplankton abundance around Shelikof Strait (Incze \& Ainaire 1994) to evaluate the

Table 3. Theragra chalcogramma. Environmental parameters used in 3 bioenergetics simulations. In-patch: values inside a patch in 1981; out-of-patch: values outside of a patch in 1981; normal-in-patch: hypothetical values within a larval patch based on observations in other years (see Fig. 6). Temperature: $6.2^{\circ} \mathrm{C}$

\begin{tabular}{|lccc|}
\hline & In-patch & $\begin{array}{c}\text { Out-of- } \\
\text { patch }\end{array}$ & $\begin{array}{c}\text { Normal- } \\
\text { in-patch }\end{array}$ \\
\hline Natural mortality $\left(\mathrm{d}^{-1}\right)$ & 0.15 & 0.15 & 0.10 \\
Growth rate $\left(\mathrm{d}^{-1}\right)$ & 0.071 & 0.067 & 0.067 \\
Larval density (per 10 $\left.\mathrm{m}^{2}\right)$ & 27440 & 1670 & 6000 \\
Larval diet; nauplii:eggs & $9: 1$ & $19: 1$ & $19: 1$ \\
\hline
\end{tabular}

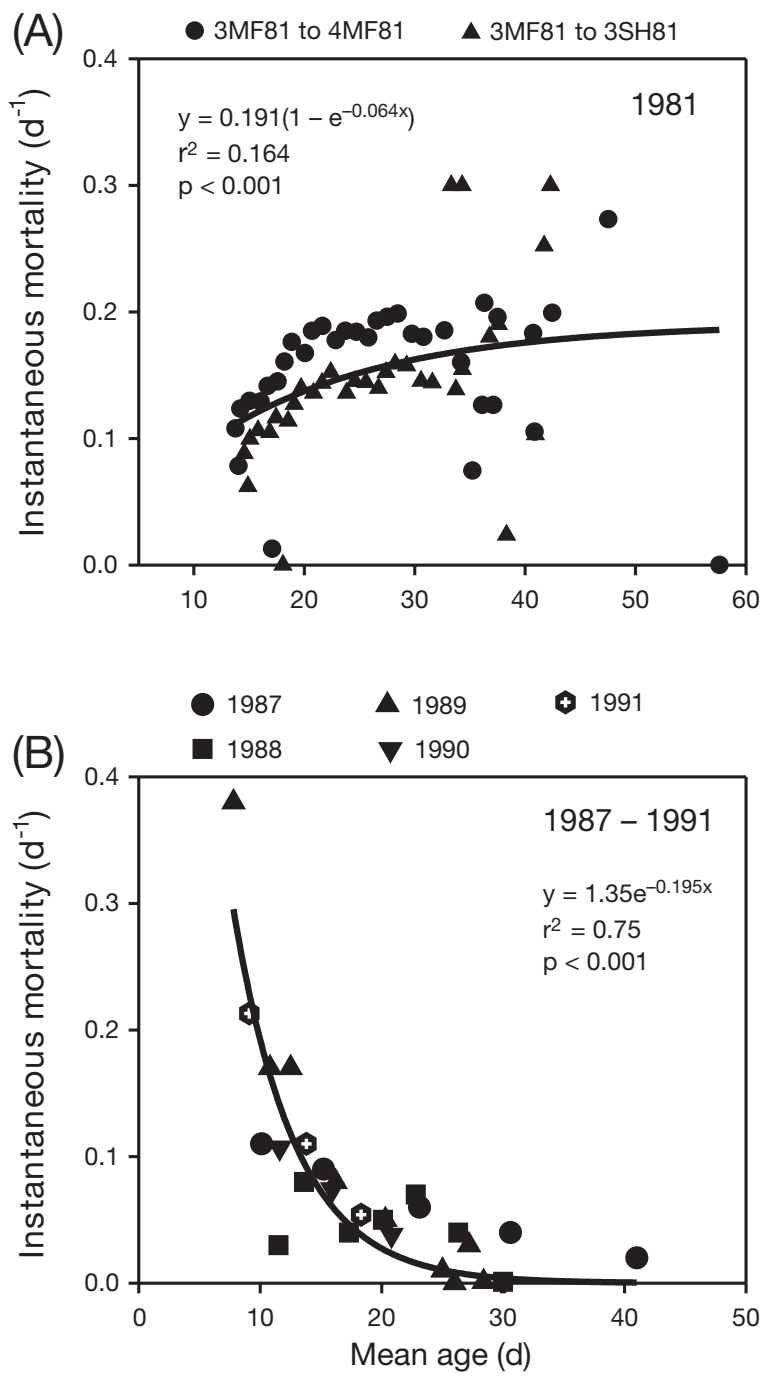

Fig. 3. Theragra chalcogramma. (A) Relationship between larval age and instantaneous mortality for 1981. (•) Calculated between the 3MF81 (early spring) and 4MF81 (late spring); ( $\mathbf{\wedge}$ ) calculated between 3MF81 (early spring) and 3SH81 (late spring). (B) Relationship between larval age and instantaneous mortality in other years (1987 to 1991)

impact of larval density on typical microzooplankton standing stocks.

\section{RESULTS}

\section{Mortality}

As noted earlier, calculation of mortality between the early and late spring cruises revealed that rates of instantaneous mortality were low during the early larval stages $\left(0.1\right.$ to $\left.0.15 \mathrm{~d}^{-1}\right)$ and increased with larval age (0.2 to $0.3 \mathrm{~d}^{-1}$; Fig. 3A). This pattern was compared to mortalities calculated in other years in the GOA (Bailey 
et al. 1996a) which demonstrated a more typical exponential pattern of exponential decline (Fig. 3B). However, upon closer examination of the model output, we determined that the model may have had a bias in attributing hatch dates to the cohorts in 1981, erroneously influencing the estimated age of the larvae in that year. This could have confounded our estimates of mortality; hence, we decided that a second, independent analysis of mortality in 1981 was required to either corroborate or refute these findings. Mortality during the late larval to early juvenile stage was examined from a stagespecific life table analysis. Mortality during 1981 (with the highest initial density) was higher than any other year from 1982 to 1996 (Fig. 4). This corroborates the finding that late larval mortality was high in 1981. These 2 estimates of unusual larval mortality in 1981 are consistent with a pattern that might be expected if density dependent competition played a significant role in overall larval survival.

\section{Body measurements and gut contents}

We examined 367 larval walleye pollock collected over the 3 ichthyoplankton cruises conducted in 1981 (Table 4). There were no significant differences in sizes $(p=0.25)$ or anal body depths $(p=0.32)$ of larvae collected in-patch versus out-of-patch; however larvae collected during the late cruises were significantly larger than larvae collected during the early cruise $(\mathrm{p}<$ 0.001). Larger larvae during the late spring cruise could be due to differences in size-selective mortality, though it is more likely that larvae grew during the 3 wk interval between cruises. There was no significant interaction between the 2 factors (patch, cruise; $p=0.06$ ). The percentage of larvae feeding was statistically similar between the cruises as well as in-patch versus out-of-patch, though a trend toward a greater proportion of feeding larvae was noted during the later cruises (Table 4). The mean number of prey ingested per larva generally increased with increasing larval

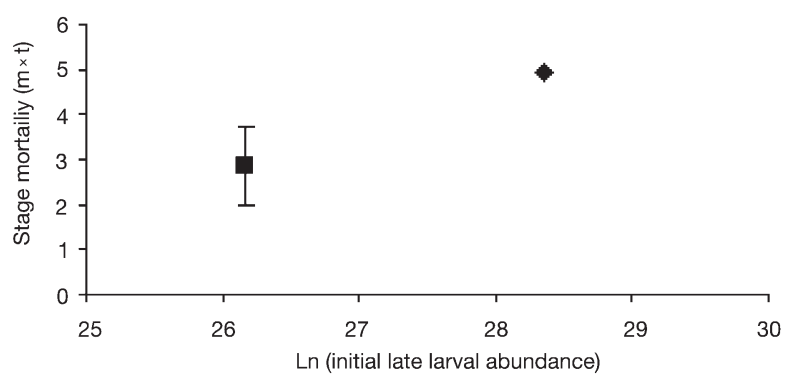

Fig. 4. Theragra chalcogramma. Stage-specific mortality $(m \times t)$ for the late larval to early juvenile period plotted against the initial late larval abundance. Shown are values for $1981(\bullet)$ and average ( $\pm 1 \mathrm{SD})$ for 1982 to $1996(\square)$

size, and no significant differences in number of prey consumed were detected between larvae in-patch or out-of-patch (Table 4). There were also no significant differences in mean prey size in-patch versus out-ofpatch, although it was noted that mean prey size among in-patch larvae tended to be smaller than larvae out-of-patch on each cruise (Table 4).

There were consistent trends in type of prey consumed by larvae in-patch and out-of-patch, with many in-patch walleye pollock larvae possessing large numbers of invertebrate eggs in the gut, both during the early and late spring cruises (Fig. 5). Eggs consumed ranged from 80 to $350 \mu \mathrm{m}$ in size, while the majority of eggs ranged from 100 to $200 \mu \mathrm{m}$ in size (87\%). The diets of larvae outside the patches were dominated by copepod nauplii (78\% for early stage larvae), although invertebrate eggs were also consumed (Fig. 6). Differences in diet between in-patch and out-of-patch larvae were not significant during the early cruise (3MF81; $\mathrm{p}>0.1$ ), even though it was noted that invertebrate eggs made up more than half of the diet among all inpatch larvae. It is likely that the lack of detection of significant differences during the early cruise was due to low power. Statistical differences in diet type were detected among late-stage larvae. Walleye pollock larvae consumed significantly greater numbers of in-

Table 4. Theragra chalcogramma. Sizes and feeding indices of larval walleye pollock collected in late April (3MF81) and late May (4MF81, 3SH81) in the Gulf of Alaska, 1981. Values presented are means \pm 1 SD unless otherwise indicated

\begin{tabular}{|c|c|c|c|c|c|c|}
\hline \multirow[t]{2}{*}{ Parameters } & \multicolumn{2}{|c|}{ 3MF81 } & \multicolumn{2}{|c|}{ 4MF81 } & \multicolumn{2}{|c|}{ _ 3SH81 } \\
\hline & In-patch & Out-of-patch & In-patch & Out-of-patch & In-patch & Out-of-patch \\
\hline Time of day (range) & $10: 20-13: 05$ & $11: 35-13: 10$ & $11: 15-15: 08$ & $12: 14-13: 51$ & $12: 31-14: 21$ & No samples \\
\hline Size (mm SL) & $5.6 \pm 0.6$ & $6.0 \pm 0.6$ & $8.5 \pm 1.4$ & $7.5 \pm 1.2$ & $8.1 \pm 1.5$ & \\
\hline Size range (mm SL) & $4.0-6.9$ & $5.0-7.1$ & $6.0-11.9$ & $4.4-10.4$ & $5.6-12.2$ & \\
\hline Anal body depth (mm) & $0.28 \pm 0.06$ & $0.29 \pm 0.05$ & $0.73 \pm 0.22$ & $0.66 \pm 0.27$ & $0.71 \pm 0.23$ & \\
\hline Total number examined & 74 & 74 & 75 & 65 & 79 & \\
\hline Feeding $(\%)$ & 78 & 80 & 100 & 94 & 91 & \\
\hline Number prey fish ${ }^{-1}$ & $2.7 \pm 2.3$ & $2.4 \pm 2.3$ & $12.2 \pm 9.4$ & $11.2 \pm 6.5$ & $4.4 \pm 3.8$ & \\
\hline Prey length $(\mu \mathrm{m})$ & $158.5 \pm 81.1$ & $214.6 \pm 95.8$ & $156.9 \pm 168.7$ & $234.3 \pm 115.3$ & $273.3 \pm 298.3$ & \\
\hline
\end{tabular}




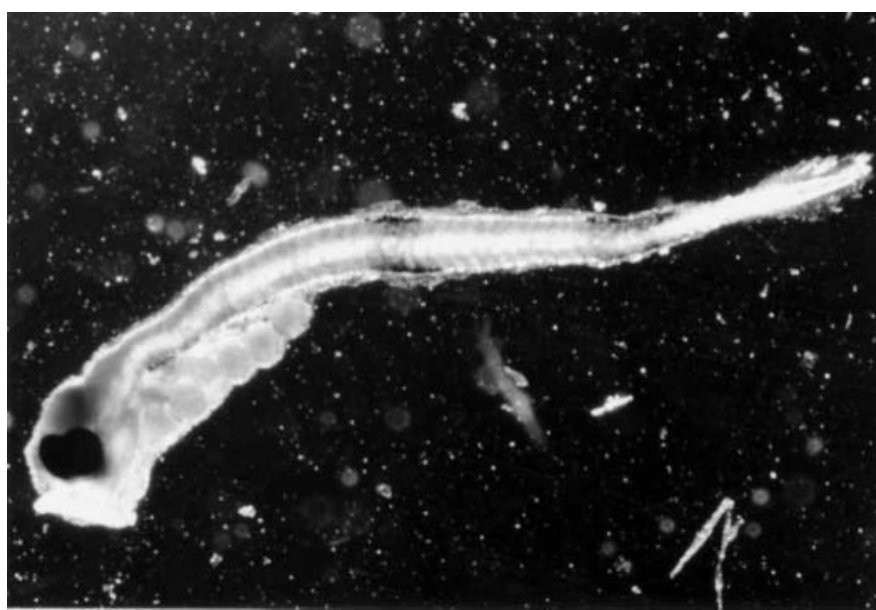

Fig. 5. Theragra chalcogramma. Representative larva collected from inside a larval patch on the early spring cruise (3MF81). Note the numbers of invertebrate eggs present in the foregut, midgut and hindgut. Actual larval size $=5.7 \mathrm{~mm}$ total length

vertebrate eggs $(p=0.03)$ and fewer copepod nauplii $(p=0.05)$ in-patch than out-of-patch. No significant differences in consumption of copepods (+ copepodids) and 'other' food items were found.

Since no significant differences in anal body depth were detected between in-patch and out-of-patch larvae in 1981, data were pooled for comparison to body depths in another year, namely 1988, a strong recruitment year. Linear regressions were fitted to describe the relationship between fish size (SL) and anal body

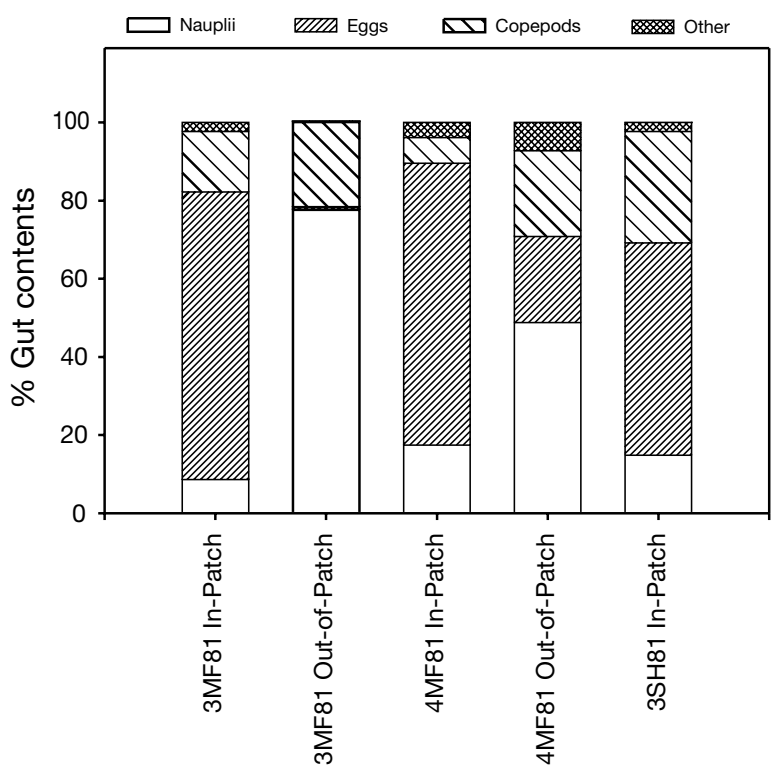

Fig. 6. Theragra chalcogramma. Percent composition of the gut contents of larvae collected inside and outside of larval patches during each cruise in 1981. 3MF81 (April 26 to May 2), 4MF81 (May 20 to May 24) and 3SH81 (May 20 to May 28) depth in 1981 and 1988, and it was found that the rate of increase was significantly greater in 1988 than in 1981 $(\mathrm{p}<0.001)$. This suggests that the overall condition of larvae collected in 1981 was worse than the overall condition of larvae in a good recruitment year (Fig. 7).

\section{Bioenergetics model}

During the $45 \mathrm{~d}$ bioenergetics simulation, larval pollock dry weight increased from 0.17 to $4.61 \mathrm{mg}$ in the in-patch scenario, and from 0.20 to $4.43 \mathrm{mg}$ in the out-ofpatch and normal-in-patch scenarios. Consumption rate of out-of-patch and normal-in-patch larvae decreased from 25.5 to $20.4 \%$ of body weight $\mathrm{d}^{-1}$ from the start to the end of the simulations. Consumption rate of in-patch larvae was slightly higher, 27.0 and $21.5 \%$ of body weight $\mathrm{d}^{-1}$ at start and end, respectively; this was due mainly to the higher proportion of eggs in their diet.

Predicted cumulative consumption of larval walleye pollock in 1981 suggests that there was a strong potential for food depletion of naupliiar resources among inpatch larvae, although no such potential was evident for larvae out-of-patch (Fig. 8A). In addition, the potential for resource depletion was not apparent for invertebrate eggs, either in the in-patch or out-of-patch scenarios (Fig. 8B). The model predicted that high, mean in-patch larval abundances (27440 larvae per $10 \mathrm{~m}^{2}$ ) could deplete the typical naupliiar resources in Shelikof Strait within 14 to $40 \mathrm{~d}$ when using estimated rates of growth and mortality. Finally, model results indicated that there was scant potential for food depletion in-patch during years of more typical larval abundance (Fig. 8A), even at very high estimates of normal larval density and using conservative estimates of mortality (Table 3).

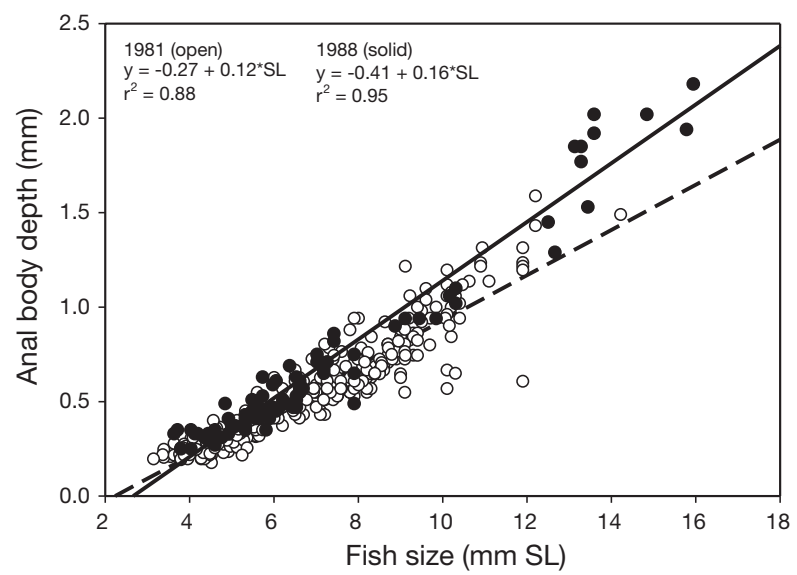

Fig. 7. Theragra chalcogramma. Relationship between fish size and anal body depth for 1981 (०) and 1988 (•). Equations for linear regressions shown. Dashed line $=1981$; solid line $=1988$ 

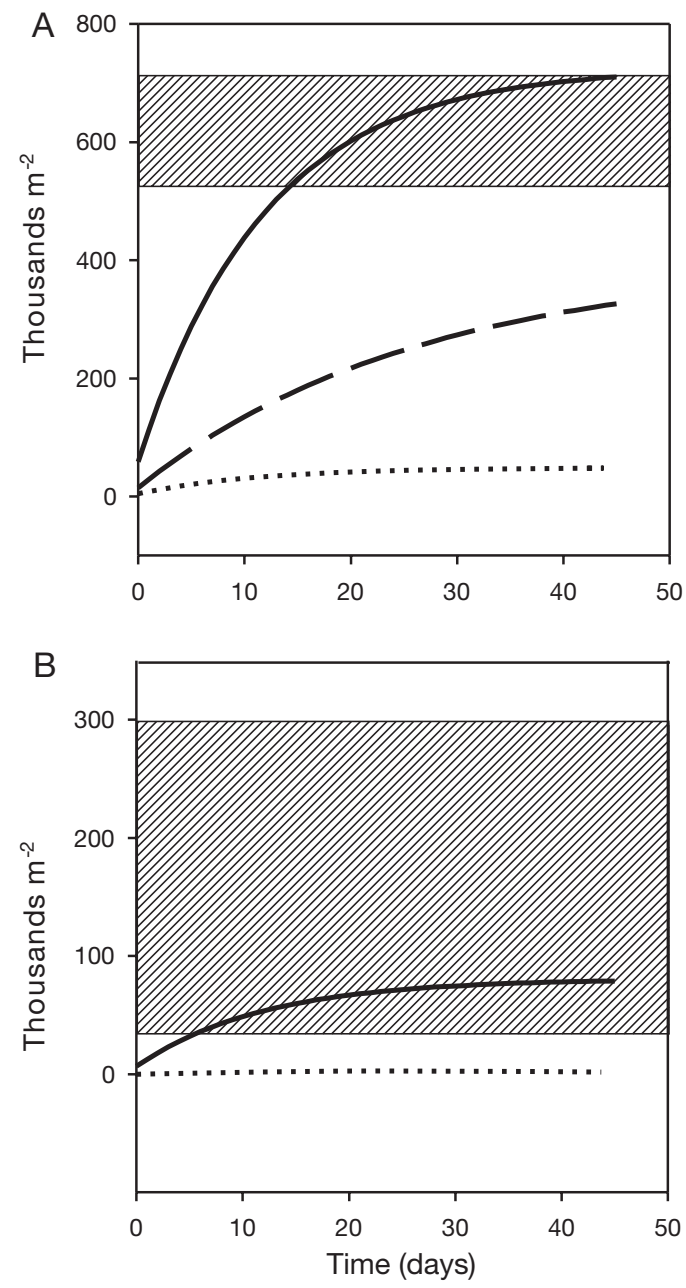

Fig. 8. Theragra chalcogramma. (A) Results of a bioenergetics simulation of walleye pollock larval population consumption of copepod nauplii. (B) Results of a bioenergetics simulation of walleye pollock larval population consumption of invertebrate eggs. Solid line $=$ in-patch; dashed line = normal-inpatch; dotted line $=$ out-of-patch; hatched area $=$ estimation of standing stock

\section{DISCUSSION}

The data presented here provide substantial support for the occurrence of density dependent prey depletion by larval walleye pollock in Shelikof Strait in 1981. Walleye pollock larvae in patches consumed greater numbers of invertebrate eggs and fewer copepod nauplii compared to their counterparts outside of patches. This shift in diet type did not appear to affect the number of prey consumed per larva in-patch relative to out-of-patch, although the mean size of prey ingested was smaller among in-patch larvae, likely reflecting their tendency to ingest eggs. Larval sizes in-patch and out-of-patch were similar, both in body length and body depth, despite the fact that overall larval condi- tion in 1981 was worse than in a year of strong recruitment (1988). Larval mortality appeared to increase with larval age in 1981, the only year in our $12 \mathrm{yr}$ time series that this phenomenon has been observed (Bailey et al. 1996a). These data suggest that the unusually high densities of larvae entrained in patches in 1981 may have locally grazed down the standing stock of copepod nauplii, resulting in a shift in feeding from nauplii, their primary food source, to feeding on invertebrate eggs. For reasons outlined below, we suggest that invertebrate eggs are not an adequate prey resource, potentially contributing to the overall poor recruitment success of the 1981 year class.

\section{Larval feeding}

We did not attempt to identify the types of invertebrate eggs ingested, although we speculate that the majority were copepod eggs. Most ingested eggs (over $85 \%$ ) ranged from 100 to $200 \mu \mathrm{m}$, coinciding with the egg sizes of a variety of copepod species (Oithona, Pseudocalanus, Metridia and Calanus) that are present in the GOA at approximately the same time as feeding larval walleye pollock. Most eggs were found loose in the gut and in many cases, there was no evidence that an adult copepod was ingested at all, indicating the majority of eggs that were consumed were probably produced by copepods that broadcast spawn. As such, most of the eggs may have been Calanus spp. (fecundity $=38$ eggs $d^{-1}$; Runge 1984) and/or Metridia spp. (fecundity 1-6 eggs $d^{-1}$; Napp et al. 1996) rather than Oithona or Pseudocalanus (egg bearers).

A few studies have demonstrated that copepod eggs are poorly digested by larval fishes. Conway et al. (1993) observed that subitaneous eggs of Acartia spp., Eurytemora spp., Oncaea spp., Corycaecus spp. and Euterpina spp. appeared to pass through the guts of larval turbot Scophthalmus maximus undigested. Conway et al. (1994) later demonstrated that the viability of eggs egested by larval turbot ranged from $0 \%$ (Corycaeus spp.) to $91.7 \%$ (Eurytemora spp.), and Flickman et al. (1994) found that $60 \%$ of the Eurytemora affinis eggs passed into the feces by Baltic herring Clupea harengus membras could be hatched to nauplii. We noted that the invertebrate eggs in the guts of walleye pollock larvae collected in 1981 appeared to be similar in shape, size, and internal content between the foregut and the hindgut, and that many of the eggs on the verge of being egested through the anal opening were visually intact (Fig. 4). If larval walleye pollock in 1981 grazed down their naupliiar prey resources and switched to eggs, it seems likely that they obtained less nutritional value from the unhatched eggs than from hatched nauplii. 
It is important to note that copepod eggs form a substantial portion of the larval walleye pollock diet even in years of typical larval abundance in the GOA and Bering Sea (Grover 1990, Canino et al. 1991, Hillgruber et al. 1995, Nakatani 1995). However, these prey items generally occur in the stomachs secondarily to copepod nauplii, usually making up only 15 to $30 \%$ of the total diet. In the present study, copepod eggs made up 50 to $75 \%$ of the diet of in-patch larvae, far exceeding the normal proportion of these prey items in the gut contents and potentially providing larvae with less energy per prey item than they would otherwise ingest.

It seems likely that the consumption of large numbers of copepod eggs by walleye pollock larvae in 1981 was due to density dependent resource depletion, although in the absence of microzooplankton data from 1981, we cannot dismiss the possibility that a mismatch occurred between larval consumption and copepod production. Such an event would also result in a scarcity of nauplii at the time of larval feeding. However, this scenario seems less probable for several reasons. First, invertebrate eggs were found in the guts of out-of-patch larvae in nearly the same proportions as during years of normal larval abundance (approximately $25 \%$ ). The remainder of the gut contents of outof-patch larvae comprised copepod nauplii (78\% for early stage larvae) or copepods and nauplii combined (71\% for late-stage larvae). If prey were limiting in 1981 due to a zooplankton production mis-match, presumably nauplii would not have been available to out-of-patch larvae. Second, the results of the bioenergetics model indicate that even conservative estimates of the densities of larvae in a patch in $1981(\bar{x}=27440$ larvae per $10 \mathrm{~m}^{2}$ ) were capable of depleting available nauplii prey resources in as little as $2 \mathrm{wk}$, irrespective of the often much higher larval densities noted during that year (50000 to 100000 larvae per $10 \mathrm{~m}^{2}$ ). Finally, the 2 approaches for estimating age-specific mortality in 1981 indicate aberrations that are consistent with notion that sufficient prey resources were available to larvae for a portion of time (as evidenced by the comparatively low mortality rates observed among young larvae), but became limiting with time (as indicated by increasing rates of mortality among older larvae and early juveniles).

\section{Larval condition}

Although we saw differences in the diets of larvae in-patch versus out-of-patch in 1981, differences in fish length, body depth and calculated growth rates $\left(G_{\mathrm{W}}\right)$ were not apparent. It is inherently difficult to determine significant differences in larval size in the wild due to the high individual variation in growth rate and larval size-at-age. Moreover, ichthyoplankton disintegrate quickly upon dying, rendering the weakest larvae unavailable to our sampling gears. As such, we can only effectively sample the larvae that are surviving in the population, the individuals that are able to grow regardless of whether they are located inside or outside of a larval patch. Therefore, our inability to determine significant size or growth rate differences among in-patch and out-of-patch larvae was not entirely unexpected.

\section{Bioenergetics model}

The bioenergetics model used to estimate larval pollock consumption corroborates well with other independent estimates of daily consumption and respiration. Yamashita \& Bailey (1989) estimated a daily consumption rate of $37.0 \%$ body weight $\mathrm{d}^{-1}$ for a $90 \mathrm{~g}$ (dry weight) larval walleye pollock. Our model predicts a rate of $36.0 \%$ body weight $\mathrm{d}^{-1}$ for a similar larval size. Although some of the Yamashita \& Bailey (1989) results were used to parameterize the model, their larval consumption estimates were independent from our model because they were assessed using non-bioenergetics methods, i.e. gut evacuation rates. Porter (1999) estimated respiration rates of larval pollock to vary from 4.6 to $2.3 \mathrm{l} \mathrm{O}_{2} \mathrm{mg}^{-1} \mathrm{~h}^{-1}$ in specimens ranging from 0.105 to $0.272 \mathrm{~g}$ dry weight, respectively. Our model predicted 2.9 and $2.61 \mathrm{O}_{2} \mathrm{mg}^{-1} \mathrm{~h}^{-1}$ for a similar size range.

The bioenergetics model that we used was relatively simple, and we intentionally excluded several factors that could potentially influence larval feeding and growth efficiency. However, these exclusions could contribute to the uncertainty of our estimates of larval consumption. For example, wind or tide turbulence (Rothschild \& Osborn 1988, MacKenzie \& Leggett 1991, Dower et al. 1997), larval visual range (Aksnes \& Utne 1997, Fiksen et al. 1998), or exposure to heterogeneous thermal scenarios (Wieser et al. 1988, Porter 1999) are a few of the factors that can increase larval prey capture probability or reduce metabolic expenditures. However, we believe that the predicted 1981 grazing impact of in-patch pollock larvae is more robust than the inherent uncertainties of the model. First, the estimate of in-patch population larval consumption should be considered conservative because it was based on high rates of larval mortality $\left(0.15 \mathrm{~d}^{-1}\right)$ equally applied throughout the $45 \mathrm{~d}$ simulation period. Second, the initial in-patch population density used in the model was actually lower than many other high larval densities observed that year (50000 to 100000 larvae per $10 \mathrm{~m}^{2}$ ). Finally, a variety of other species consume copepod nauplii in addition to larval walleye pollock (other larval fishes, polychaetes, crustacean larvae and jelly- 
fish); therefore, the grazing effect of walleye pollock alone in 1981 actually underestimates the effect of an ecosystem of predators on standing stocks (Brodeur \& Terazaki 1999, Purcell \& Sturdevant 2001).

It also should be noted that we intentionally conducted the model using a static estimate of naupliiar abundance, eliminating production from the model simulation. Of course, copepod production would contribute to the overall microzooplankton standing stock. However, a variety of assumptions need to be made prior to the inclusion of copepod production into the model, including accurate production estimates for each copepod species in the GOA, assumptions regarding the availability of phytoplankton to assure maximum egg production as well as assumptions of hatching success of copepod nauplii in 1981.

\section{Mortality}

Our estimates of mortality may have been confounded if drift or advection served to transport larvae out of the sampling range. Indeed, mortality calculated between the 3MF81 and 4MF81 cruises may overestimate actual field rates since the 4MF81 survey grid was essentially identical to that of the early spring cruise and did not account for larval drift. Estimating larval drift between these same 2 cruises, Kim \& Bang (1990) determined that approximately $20 \%$ of the larvae may have been flushed out of the grid. Compensating for this loss, they suggested that mortality rates were approximately $0.07 \mathrm{~d}^{-1}$, considerably lower than our calculations. However, our estimates of mortality derived between 3MF81 and 3SH81 are probably more reliable, since the $3 \mathrm{SH} 81$ grid was extended to the southwest, and these values compare well with our values derived between 3MF81 and 4MF81. Moreover, an eddy resolving biophysical model (S-Coordinate Primitive Equation Model, SPEM; Hermann \& Stabeno 1996, Stabeno \& Hermann 1996) of circulation in Shelikof Strait suggests that the flow regime in 1981 was comparatively low and that a number of eddies were part of the flow field. A lower flow regime coupled with a increased number of larvae retaining eddies makes it less likely that walleye pollock larvae were rapidly flushed out of Shelikof Strait in 1981 and more probable that the larvae were retained within the confines of our sampling grids.

In summary, our observations present evidence that particularly dense aggregations of larvae appear to be capable of locally depleting the prey community. Such phenomena may occur as events rather than as typical occurrences, but the capacity for such episodes to shape recruitment among marine fish populations should be recognized.
Acknowledgements. Many thanks to the members of Fisheries Oceanography Coordinated Investigations (FOCI) who were involved in the collection and processing of the ichthyoplankton samples. J. Napp and C. Baier helped with several gut content identifications. K. Mier assisted with statistical analyses and interpretation. A. Hermann provided access to the SPEM model for 1981. M. Busby helped with photography and S. Picquelle and D. Wion provided support with ArcView. S. Sogard provided comments on an earlier draft of this manuscript. This publication is supported by a grant to the Joint Institute for the Study of the Atmosphere and Ocean (JISAO) under NOAA Cooperate Agreement No. NA17RJ1232. This is JISAO Contribution Number 903 and FOCI Contribution Number 441.

\section{LITERATURE CITED}

Aksnes DL, Utne ACW (1997) A revised model of visual range in fish. Sarsia 82(2):137-147

Bailey KM, Canino MF, Napp JM, Spring SM, Brown AL (1995) Contrasting years of prey levels, feeding conditions, and mortality of larval walleye pollock Theragra chalcogramma in the western Gulf of Alaska. Mar Ecol Prog Ser 119:11-23

Bailey KM, Picquelle SM, Spring S (1996a) Mortality of larval walleye pollock Theragra chalcogramma in the western Gulf of Alaska, 1988-91. Fish Oceanogr 5(Suppl 1):124-136

Bailey KM, Brodeur RD, Hollowed AB(1996b) Cohort survival patterns of walleye pollock, Theragra chalcogramma, in Shelikof Strait, Alaska: a critical factor analysis. Fish Oceanogr 5(Suppl 1):179-188

Brodeur RD, Terazaki M (1999) Springtime abundance of chaetognaths in the shelf region of the northern Gulf of Alaska, with observations on the vertical distribution and feeding of Sagitta elegans. Fish Oceanogr 8(Suppl 2): 93-103

Canino MF, Bailey KM (1995) Gut evacuation of walleye pollock larvae in response to feeding conditions. J Fish Biol 46:389-403

Canino MF, Bailey KM, Incze LS (1991) Temporal and geographic differences in feeding and nutritional condition of walleye pollock larvae Theragra chalcogramma in Shelikof Strait, Gulf of Alaska. Mar Ecol Prog Ser 79:27-35

Ciannelli L, Brodeur R, Buckley TW (1998) Development and application of a bioenergetics model for juvenile walleye pollock. J Fish Biol 52:879-898

Clarke ME (1984) Feeding behavior of larval walleye pollock, Theragra chalcogramma (Pallas) and food availability to larvae pollock in the southeastern Bering Sea. PhD dissertation, University of California, San Diego

Conway DVP, Tranter PRG, Coombs SH (1993) Digestion of natural food by larval and post-larval turbot Scophthalmus maximus. Mar Ecol Prog Ser 100:221-231

Conway DVP, McFadzen IRB, Tranter PRG (1994) Digestion of copepod eggs by larval turbot Scophthalmus maximus and egg viability following gut passage. Mar Ecol Prog Ser 106:303-309

Cushing DH (1983) Are fish larvae too dilute to affect the density of their food organisms? J Plankton Res 5:847-854

Dower JF, Miller TJ, Leggett WC (1997) The role of microscale turbulence in the feeding ecology of larval fish. Adv Mar Biol 31:169-220

Duffy JT, Epifanio CE, Cope JS (1996) Effects of prey density on the growth and mortality of weakfish Cynoscion regalis (Bloch and Schneider) larvae: experiments in field enclosures. J Exp Mar Biol Ecol 202:191-203 
Fiksen OE, Utne ACW, Aksnes DL, Eiane K, Helvik JV, Sundby S (1998) Modelling the influence of light, turbulence and ontogeny on ingestion rates in larval cod and herring. Fish Oceanogr 7(3-4):355-363

Flickman J, Vuorinen I, Christiansen M (1994) Calanoid copepod eggs survive passage through fish digestive tracts. ICES J Mar Sci 51:127-129

Gomez-Gutierrez J, Peterson W (1999) Egg production rates of eight calanoid copepod species during summer 1997 off Newport, Oregon, USA. J Plankton Res 21:637-657

Grover JJ (1990) Feeding ecology of late-larval and earlyjuvenile walleye pollock Theragra chalcogramma from the Gulf of Alaska in 1987. Fish Bull US 88:463-470

Hermann AJ, Stabeno PJ (1996) An eddy-resolving model of circulation on the western Gulf of Alaska shelf: 1. Model development and sensitivity analyses. J Geophys Res 101(C1):1129-1149

Hewett SW, Johnson BL (1992) Fish Bioenergetics Model 2, an upgrade of a generalized bioenergetics model of fish growth for microcomputers. University of Wisconsin Sea Grant Technical Report Number WIS-SG-92-250, p 79

Hillgruber N, Haldorson L, Paul AJ (1995) Feeding selectivity of larval walleye pollock Theragra chalcogramma in the oceanic domain of the Bering Sea. Mar Ecol Prog Ser 120: $1-10$

Incze LA, Ainaire T (1994) Distribution and abundance of copepod nauplii and other small (40-300 m) zooplankton during spring in Shelikof Strait, Alaska. Fish Bull 92:67-78

Incze LS, Clarke EM, Goering JJ, Hishiyama T, Paul AJ (1984) Eggs and larvae walleye pollock and relationship to the planktonic environment. In: Proceedings of the workshop on walleye pollock and its ecosystem in the eastern Bering Sea. US Department of Commerce. NOAA Tech Memo NMFS F/NWC-62, p 292

Incze LS, Siefert DW, Napp JM (1997) Mesozooplankton of Shelikof Strait, Alaska: abundance and community composition. Cont Shelf Res 17(3):287-305

Kim S, Bang B (1990) Oceanic dispersion of larval fish and its implication for mortality estimates: case study of walleye pollock larvae in Shelikof Strait, Alaska. Fish Bull US 88: 303-311

MacKenzie BR, Leggett WC (1991) Quantifying the contribution of small-scale turbulence to the encounter rates between larval fish and their zooplankton prey: effects of wind and tide. Mar Ecol Prog Ser 73(2-3):149-160

Nakatani T (1995) Monthly change in food size of larval walleye pollock Theragra chalcogramma at the initial feeding stage in Funka Bay and surrounding vicinity in Hokkaido. Fish Sci 61(3):387-390

Napp JM, Incze LS, Ortner PB, Siefert DLW, Britt L (1996) The plankton of Shelikof Strait, Alaska: standing stock, production, mesoscale variability and their relevance to larval fish survival. Fish Oceanogr 5(Suppl 1):19-38

Neilsen T, Munk P (1998) Zooplankton diversity and the predatory impact by larval and small juvenile fish at the Fisher Banks in the North Sea. J Plankton Res 20(12):2313-2332

Nishiyama T (1981) Food energy requirements of walleye pollock in the southeast Bering Sea. Processes and resources of the eastern Bering Sea shelf (PROBES) Progress Report. Institute of Marine Science, University of Alaska, Fairbanks, AK, p 269-308

Editorial responsibility: Kenneth Sherman (Contributing Editor), Narragansett, Rhode Island, USA
Paul AJ, Coyle KO, Haldorsen L (1991) Interannual variations in copepod nauplii prey of larval fish in an Alaskan Bay. ICES J Mar Sci 48:157-165

Pedersen BH (1993) Growth and mortality in young larval herring (Clupea harengus); effects of repetitive changes in food availability. Mar Biol 117:547-550

Pepin P, Penney R (2000) Feeding by a larval fish community: impact on zooplankton. Mar Ecol Prog Ser 204:199-212

Porter SM (1999) The effect of temperature, size, and light on the respiration rate of walleye pollock, Theragra chalcogramma, larvae. MS thesis, University of Washington, Seattle

Posgay JA, Marak RR (1980) The MARMAP bongo zooplankton samplers. J Northwest Atl Fish Sci 1:91-99

Purcell JE, Sturdevant MV (2001) Prey selection and dietary overlap among zooplanktivorous jellyfish and juvenile fishes in Prince William Sound, Alaska. Mar Ecol Prog Ser 210:67-83

Rothschild BJ, Osborn TR (1988) Small-scale turbulence and plankton contact rates. J Plankton Res 10(3):465-474

Runge JA (1984) Egg production of the marine planktonic copepod, Calanus pacificus, Brodsky: laboratory observations. J Exp Mar Biol Ecol 74:53-66

Schnute J (1981) A versatile growth model with statistically stable parameters. Can J Fish Aquat Sci 38:1128-1140

Shima M, Bailey KM (1994) Comparative analysis of ichthyoplankton sampling gear for early life stages of walleye pollock (Theragra chalcogramma). Fish Oceanogr 3(1): 50-59

Stabeno PJ, Hermann AJ (1996) An eddy-resolving model of circulation on the western Gulf of Alaska shelf: 2. Comparison of results to oceanographic observations. J Geophys Res 101(C1):1151-1161

Stabeno PJ, Schumacher JD, Bailey KM, Brodeur RD, Cokelet ED (1996) Observed patches of walleye pollock eggs and larvae in Shelikof Strait, Alaska: their characteristics, formation and persistence. Fish Oceanogr 5:81-91

Theilacker GH, Bailey KM, Canino MF, Porter SM (1996) Variations in larval walleye pollock feeding and condition: A synthesis. Fish Oceanogr 5(Suppl 1):112-123

Van der Meeren T, Næss T (1993) How does cod (Gadus morhua) cope with variability in feeding conditions during early larval stages? Mar Biol 116:637-647

Wieser W, Forstner H, Schiemer F, Mark W (1988) Growth rates and growth efficiencies in larvae and juveniles of Rutilus rutilus and other cyprinid species: effects of temperature and food in the laboratory and in the field. Can J Fish Aquat Sci 45(6):943-950

Winberg GG (1956) Rate of metabolism and food requirements of fishes. Belorussian University, Minsk, p 253 (translated by the Fisheries Research Board of Canada, translation No. 164, 1960)

Yamashita Y, Bailey KM (1989) Laboratory study of the bioenergetics of larval pollock, Theragra chalcogramma. Fish Bull 87:525-536

Yin MC, Blaxter JHS (1986) Morphological changes during growth and starvation of larval cod (Gadus morhua L.) and flounder (Platichthys flesus L.). J Exp Mar Biol Ecol 104: 215-228

Zar JH (1984) Biostatistical analysis. Prentice Hall, Englewood Cliffs, NJ

Submitted: December 5, 2001; Accepted: August 1, 2002

Proofs received from author(s): October 29, 2002 